Jurnal Konstruksi Hukum | ISSN: 2746-5055

Vol. 2, No. 2, Mei 2021, Hal. 244-249| Tersedia online di

https://www.ejournal.warmadewa.ac.id/index.php/jukonhum

DOI: https://doi.org/10.22225/jkh.2.2.3214.244-249

\title{
TINJAUAN YURIDIS PERTANGGUNGJAWABAN MUTLAK (STRICT LIABILITY) DALAM HUKUM PERLINDUNGAN KONSUMEN
}

\author{
Putu Rido Widiya Widnyana, Anak Agung Istri Agung, Ni Gusti Ketut Sri Astiti \\ Kultas Hukum, Universitas Warmadewa, Denpasar - Bali, Indonesia \\ ridowidnyana99@gmail.com, notistria@yahoo.com, notarisppatsriastiti@yahoo.com
}

\begin{abstract}
Abstrak
Konsumen sebagai objek kegiatan usaha untuk meraih keuntungan yang besar namun konsumen berada dalam posisi yang lemah sehingga kedudukan konsumen terhadap produsen menjadi tidak seimbang, sehingga konsumen perlu mendapatkan perlindungan hukum. Mencari kelemahan konsumen dan memojokkan konsumen merupakan cara yang merugikan konsumen merupakan peristiwa yang dilakukan oleh pihak pelaku. Metode yang dipakai pada penulisan ini menggunakan penelitian hukum normatif yaitu mengkaji permasalahan menggunakan dasar hukum berupa peraruran perundang-undangan dan ditunjang pendapat para sarjana yang masih ada pada literatur. Sehingga penting unruk mengkaji prinsip pertanggungjawaban mutlak (strict liability) dalam hukum perlindungan konsumen dan ketentuan pertanggungjawaban mutlak (strict liability) pelaku usaha terhadap konsumen dalam hukum perlindungan konsumen. Adapun simpulannya merupakan prinsip pertanggungjawaban mutlak (strict liability) dalam hukum perlindungan konsumen yaitu kerugian yang dialami oleh konsumen mengenai kerugian jasa atau barang yang telah dibeli wajib diganti oleh pelaku usaha, dan apabila pelaku usaha melakukan kelalain dan kerugian terhadap konsumen dapat diberikan sanksi sebagaimana sudah ditentukan Undang-Undang No. 8 Tahun 1999 tentang pert indungan konsumen.
\end{abstract}

Kata Kunci: Pertanggungjawaban, Mutlak, Pelaku Usaha, Perlindungan Konsumen.

\begin{abstract}
Abstact
Consumers become objects of business activities to gain large profits. Stiff, consumers' position towards producers is not balanced because consumers are weak, so consumers need to get legal protection. Business actors often respond to events that harm consumers by cornering consumers and looking for consumer weaknesses. The method used in this writing uses nonnative legal research, namely examining problems using a regular basis in statutory regulations and supported by scholars' opinions in the literature. It is essential to explore the principle of absolute liability(strict liability)in consumerprotectionlaw and the provisionsof business actors' strict liabilityto consumers'protectionlaw. As for the conclusion, there is the principle of absolute liability (strict liability) in consumer protection law, namely that business actors are obliged to compensatefor the loss of goods and servicesthat consumers have purchasedforlosses sufferedby consumers, and if the business actor does negligence and failure to consumers can be given sanctions as stipulated in Law No. 8 of 1999 concerning consumer protection.
\end{abstract}

Keywords: Absolute: Responsibility,Business Actors, Consumer Protection.

\section{PENDAHULUAN}

Berbagai jenis dan variasi mengenai barang dan jasa yang dihasilkan telah mengalami perkembangan ekonomi yang sangat pesat (Zulham, 2013:1) Kebutuhan jasa dan barang yang diinginkan dapat dipenuhi dengan berbagai pilihan sehingga konsumen sangat diuntungkan pada kondisi seperti ini. Namun konsumen berada dalam posisi yang tidak menguntungkan karena posisi konsumen terhadap produsen berada dalam keadaan yang tidak sama. Cara penjualan dan promosi yang dapat menyebabkan konsumen mengalami kerugian disebabkan karena konsumen hanyalah dijadikan sebagai objek untuk mendapatkan uang atau memperoleh keuntungan (Gunawan \& Yani, 2003 12).

Konsumen untuk memenuhi kebutuhan hidupnya sangat bergantung dalam pelaku usaha, sehingga pelaku usaha dituntut untuk menciptakan suatu produk yang efisien, bemilai tinggi, dan berkualitas. Adanya informasi yang jelas adalah salah satu hak dari konsumen sehingga konsumen tidak ragu dalam membeli dan memakai produk tersebut. (Husni dan Neni, 2000:18) Pelaku usaha untuk bisa mencapai target usaha yang mana berorienta untuk memperoleh keuntungan yang sebesarbesarnya dengan pengeluaran yang sekecil-kecilnya, sehingga tidak terjadinya penyimpangan yang melanggar berdasarkan hak-hak yang dimiliki oleh konsumen. Memperjuangkan hak-hak konsumen 
dapat dilakukan dengan tercapainya keseimbangan antara perlindungan konsumen sebagai cara yang paling utama unruk dilakuka. (Miru, 2013:102) Bersiap untuk menyongsong era perdagangan bebas yang akan datang atas rurnitnya masalah yang menimpa perl indungan konsumen harus diberikan jalan keluar agar usaha dalam memperjuangkan perlindungan kepentingan konsumen dapat dilaksanakan dengan baik (Celina,2014 5).

Pada bidang ekonomi dan usaha yang dikenai dampak terjadinya globalisasi dari munculnya perdagangan bebas. Kesempatan untuk berpartisipasi dalam perdagangan bebas dan peluangnya dirni liki oleh setiap orang di setiap negara yang merupakan konsekuensi atas terjadinya perdagangan bebas. Memperoleh keunrungan dari konsumen yang membutuhkanjasa atau produk barang merupakan tanda dari industri yang semakin tumbuh dan berkembang pesat. Upaya untuk melindungi industri-industri tersebut, pada dasarnya muncul karena pertumbuhan industri di berbagai wilayah yang sangat pesat. Laissezfaire merupakan salah satu upaya dalam melindungi industri ini yang merupakan paham pasar bebas. Biarkan merupakan arti dari istilah Perancis yang dikenal dengan Laissez faire. Tidak mencampuri kehidupan masyarakat merupakan doktrin yang dilakukan oleh pemerintah mengenai istilah ini. Sehingga seseorang dapat melaksanakan apa yang diinginkannya asalkan tidak melanggar hukum dan tetap menghargai masyarakat lain (Paul, 2003:157).

Konsumen memerlukan perlindungan hukum karena konsumen memiliki kedudukan yang lemah atas posisi yang dimiliki antara Pemerintah, produsen, dan konsumen. Mencari kelemahan korban dan memojokkan konsumen merupakan perbuatan yang sangat merugikan masyarakat dan sering dilakukan oleh pihak pelaku usaha. Menuduh konsumen sebagai penyebab terjadinya peristiwa tersebut dan menyatakan tindakan konsumen sebagai penghinaan merupakan perbuatan pihak pelaku usaha untuk menutupi dan melepaskan tanggung jawabnya. (Siahaan, 2005) Rendahnya tingkat kesadaran konsumen akan haknya dilihat sangat perlu memperoleh prioritas perlindungan yang utama,khususnya hak untuk mendapatkan ganti kerugian akibat cacat produk (defect) yang dipasarkan oleh produsen, maka produsen dituntut untuk bisa berdaya saing tinggi membentuk produk yang semakin bermuru, bernilai tambah yang tinggi, dan menuntut produsen agar dapat bertanggung jawab secara sadar di depan hukum. (Saefullah, 2000 42)

Faktor-faktor yang yang dapat mempengaruhi perilaku setiap anggota masyarakat merupakan hat yang umum ditemui di kehidupan sehari-hari. Faktor-faktor ini terdiri dari peraturan-peraturan yang berlandaskan hukum atas kekuatan sosial, politik dan pihak-pihak yang berwenang lainnya (Satjipto, 1997:36). Arti pentingnya Hukurn Perlindungan Konsumen tersebut dijelaskan, sebagai berikut Perlindungan konsumen mempersoalkan perlindungan (hukum) yang diberikan kepada konsumen dalam usahanya untuk memperoleh barang dan jasa berdasarkan kemungkinan timbulnya kerugian karena penggunaannya, rnaka hukum perlindungan konsumen bisa dikatakan menjadi aruran yang mengarur mengenai pemberian perlindungan pada konsumen dalam rangka pemenuhan kebutuhannya sebagai konsumen (Janus, 2014 37). Menurut (Barda Nawawi Arief, 2007:160) kebijakan kriminal bisa ditempuh lewat jalan penal dan nonpenal. Jalur penal terlihat menggunakan adanya ketentuan sanksi pidana pada Pasal 61 hingga Pasal 63 dan Jalur non penal, diantaranya penyelesaian sengketa gugatan (perdata) melalui pengadilan (Pasal 45-46). Pasal I0 dari UndangUndang No. 8 Tahun 1999 mengenai Hukum Perlindungan Konsumen bagi pelaku usaha berisi bahwa "Pelaku usaha dalarn menawarkan barang dan/atau jasa yang ditujukan untuk diperdagangkan dilarang rnernperlihatkan, mempromosikan, mengiklankan, atau menciptakan pernyataan yang tidak benar atau menyesatkan tentang"

a) Harga atau tarif suatu barang dan/atau jasa.

b) Kegunaan suatu barang dan/atau jasa.

c) Kondisi, tanggungan, jaminan, hak atau ganti rugi atas suatu barang dan/atau jasa.

d) Tawaran potongan harga atau hadiah menarik yang ditawarkan.

e) Bahaya penggunaan barang dan/atau jasa.

Berdasarkan hukum perlindungan konsumen, terdapat tanggung jawab mutlak (strict liability) yang juga dianggap menjadi tanggung jawab risiko (risk liability). Dalam kenyataannya masih ditemukan pemberitahuan dalam toko atau warung yang berbunyi Barang yang telah dibeli, tidak bisa dikembalikan. Hal ini terkait erat dengan pengalihan tanggung jawab produsen pada konsumen. Agar tidak ada penyimpangan antara produsen terhadap konsumen. Pelaku bisnis tidak akan dirugikan oleh piranti hukum yang berfungsi untuk melindungi konsumen, Tapi ha! ini akan mendukung persaingan 
dalarn menyediakan jasa dan barang yang berkualitas, mendorong lahirnya perusahaan yang tangguh dalarn menghadapi era globalisasi, dan mendorong iklim berusaha yang sehat. (Sadar, 2012:3). Berdasarkan pemaparan dari latar belakang tadi rnaka didapat suatu rumusan permasalahan, yang pertama Bagai man a prinsip pertanggungjawaban mutlak (strict liability) dalam hukum perlindungan konsumen. Yang kedua Bagaimana ketentuan pertanggungjawaban mutlak (strict liability) pelaku usaha terhadap konsumen dalam hukum perlindungan konsumen.

\section{METODE PENELITIAN}

Metode penelitian yang digunakan dalam menyusun materi nu yaitu penelitian ini menggunakan jenis penelitian yuridis normatif dengan mengkaji peraturan perundang-undangan dan ditunjang oleh konsep-konsep pendapat para sarjana/doktrin yang terdapat dalam literatur. Dalam penelitian ini digunakan pendekatan menggunakan suatu konsep dan pendekatan perundang-undangan, yaitu pendekatan suatu konsep dan pendekatan dalam perundang-undangan dalam hukum positi $\mathrm{f}$ di Indonesia dan berdasarkan konsep-konsep dari pendapat para sarjana berkaitan dengan permasalahan yang dibahas. Adapun beberapa sumber hukum primer dan sekunder yang dipergunakan yaitu Undang-Undang No 8 Tahun 1999 Tentang Perlindungan Konsumen. Selain itu juga berpedoman dalam literature-literatur, artikel-artikel, jurnal hukum, dan yang lain terkait dengan penjelasan definisi suatu kata yang berkaitan dengan judul yang diangkat.

\section{HASIL DAN PEMBAHASAN}

Prinsip Pertanggungjawaban Mutlak (Strict Liability) Dalam Hukum Perlindungan Konsumen Perbuatan melawan hukum (tort) didasari oleh bentuk khusus dari Strict Liability yaitu kesalahan yang tidak berdasarkan perbuatan melawan hukum mengenai prinsip pertanggungjawaban sebagaimana tort umumnya. Karena perbuatan melawan hukum tersebut maka pelaku usaha pribadi wajib bertanggung jawab atas kerugian yang ada. Kesalahan yang ada tidak lagi dipersoalkan pada strict liability atau prinsip pertanggungjawaban mutlak ini. Namun pelaku usaha wajib bertanggung jawab atas konsumen yang mengalami kerugian karena pelaku usaha yang kurang hati-hati dan kerugian yang ditimbulkan oleh produknya yang cacat karena seharusnya pelaku usaha dapat rnencegah ha! yang tidak menyenangkan ini (Shidarta, 2000 62).

Terdapat tiga bagian penting mengenai penerapan prinsip tanggung jawab di Indonesia. Pertama penerapan prinsip tanggungjawab mutlak mengenai pembaruan dan perkembangan hukum perlindungan konsumen dipengaruhi oleh faktor-faktor eksternal hukum. Kedua, di Indonesia telah diterapkan penerapan prinsip tanggung jawab mutlak dalam elemen budaya hukum dan struktur yang merupakan faktor internal sistem hukum. Ketiga, Undang-undang mengatur prinsip tanggung jawab mutlak terhadap substansi atau ruang lingkup materi (Innocentius, 2004:287).

Sebaliknya pembuktian akan mud ah dilakukan, khususnya mengenai tanggung jawab produk yang merupakan salah satu bidang perlindungan konsumen yang dapat digunakan pada konsep strict liabilityini dapat melindungi konsumen melalui Undang-Undang No. 8 Tahun 1999 tentang Perlindungan Konsumen Pasal 19 yang menyatakan bahwa kerugian konsurnen akibat mengkonsumsi barang yang diperdagangkan, pencemaran, dan kerusakan akan diberikan ganti rugi oleh pelaku usaha yang bertanggungjawab atas perbuatan tersebut. Posisi yang sulit bagi pelaku usaha ini terjadi karena konsumen memiliki posisi yang lebih lemah jika dibandingkan dengan posisi pelaku usaha. Seperti dalam menghadapi suatu kasus, pelaku usaha akan menggunakan jasa ahli hukum yang memerlukan biaya tidak sedikit. Meskipun para ahli dapat membedakan mengenai kedua terminologi ini, prinsip tanggung jawab absolut (absolute liability) seringkali disamakan dengan prinsip tanggung jawab mutlak (strict liability) (Shidarta, 2000 62). Faktor yang menentukan tidak menjadi penentu kesalahan berdasarkan prinsip tanggung jawab pada strict liability. Namun, keadaan force majeure yang merupakan contoh dari tanggung jawab dapat dibebaskan dari kemungkinan pengecualian yang terjadi.

Sebaliknya, tidak ada pengecualian mengenai prinsip tanggung jawab tanpa kesalahan yang terdapat pada absolute liability. Subjek dapat memiliki rasa tanggungjawab atas kesalahannya karena memiliki pandangan yang sama pada hal tersebut, Tahapan yang terjadi mengenai perkembangan hukum merupakan hasil akhir pada prinsip tanggung jawab yang terbentuk. Wanprestasi (breach of warranty) dan kelalaian/kesalahan (negligence) merupakan unsur prinsip tanggung jawab terhadap 
kepentingan konsumen karena dinilai lebih res pons if secara mutlak. Product liabilityatau tanggung jawab produk terjadi karena pembentukan hukum ekonomi nasional yang mengalami perubahan karena memperhatikan mengenai lembaga hukum yang memiliki dimensi intemasional. Produsen dan konsumen mengalami tanggung jawab yang tidak seimbang sehingga memunculkan product liability. Consumer oriented terjadi karena strategi yang diubah oleh pihak pemasaran produk karena menganggap product oriented sudah tidak bisa diterapkan lagi oleh produsen. Prinsip tanggungjawab mutlak (strict liability)yang dianut merupakan tanggung jawab pada product liability karena kehatihatian produk oleh produsen (Widijantoro, 1998:5).

Konsumen yang merasa dirugikan karena pemasaran produk oleh produsen barang, mendapatkan hukum perlindungan konsurnen pada prinsip tanggung jawab mutlak yang biasanya dilakukan oleh para pelaku usaha. Productliability ialah asas tanggung jawab pada kasus ini. Penggunaan produk yang telah dipasarkan dan digunakan jasa atau produknya sehingga konsumen mengalami kerugian, maka konsurnen akan mendapat tanggung jawab dari produsen menurut asas ini (Celina, 2019:93). Terdapat 3 hal yang dapat dilakukan berdasarkan gugatan product liabilitya) Breach of warranty atau pelanggaran jaminan. Contoh, deskripsi yang tertera dalam kemasan produk tidak sesuai dengan khasiat yang sebenarnya.

a) Negligence atau kelalaian produsen. Contoh, obat yang dibuat tidak sesuai dengan standar BPOM karena kelalaian produsen obat.

b) Strict liability atau tanggung jawab mutlak yang diterapkan.

Tanggung jawab profesional (professionalliability) dan tanggung jawab produk (product liability) yang merupakan dua prinsip penting diakomodasi oleh Undang-Undang Nomor 8 Tahun 1999 tentang Perlindungan Konsumen. Cacat yang melekat pada suatu produk sehingga konsumen mengalami kerugian merupakan tanggung jawab produsen yang dikenal dengan tanggung jawab produk (Shidarta, 2000 80). Di lain pihak, konsumen yang menggunakan jasa profesional akan dilindungi berdasarkan tanggung jawab profesional di bidang jasa (Shidarta, 2000 82). Barang adalah sesuatu yang dapat konsurnen manfaatkan, menggunakan, memakai, memperdagangkan, dan menghabiskan. Sedangkan produk dalam hukum tanggung jawab hanya bisa dikaitkan dengan barang, tidak dikaitkan dengan jasa jika rnengacu di beberapa negara lain. Dengan demikian, inti dari prinsip pertanggungjawaban mutlak (strict liability) dalam hukum perlindungan konsurnen merupakan mengenal seluruh arti dari penanggungjawaban yang dimana produsen berkewajiban mengganti kerugian jasa atau barang yang sudah dibeli oleh konsumen yang mengalami kerugian sehingga harus bertanggung jawab secara harus atas kesalahan yang diperbuat oleh pelaku usaha sebagaimana ha! tersebut sudah dilindungi menggunakan Undang• Undang No. 8 Tahun 1999 tentang Perlindungan Konsurnen. Ketentuan Pertanggungjawaban Mutlak (Strict Liability) Pelaku Usaha Terbadap Konsumen Dalam Hukum Perlindungan Konsumen.

Strict Liability merupakan proses bertanggung jawab yang ketat maka dari itu produsen wajib melakukan tanggung jawab atas kesalahannya terhadap konsurnen dan terdapat kerugian pada hal tersebut, mengenai hal itu pemerintah mengeluarkan sebuah peraturan yaitu UU No. 8 Tahun 1999 tentang Perlindungan Konsumen.

Undang-undang tersebut rnengarur mengenai pertanggungjawaban pelaku usaha untuk bisa mernpertanggung jawabkan kelalaiannya terhadap konsumen. Masalah tanggung jawab pelaku usaha terhadap kerugian yang dialami konsumen dalam Undang-Undang Perlindungan Konsumen, tanggungjawab mutlak (strict liability) sebagaimana yang mengatur tentang Penanggungjawaban Pelaku Usaha pada Pasal 19, Pasal 20, Pasal 21, Pasal 24, Pasal 25, Pasal 26, dan Pasal 27 Bab VI. Substansi berdasarkan pasal-pasal diatas yaitu bahwa (Ahmad Miru \& Sutarrnan Yodo,2017 130-164) a) Tanggung jawab pelaku usaha mencakup segala kerugian yang meliputi konsumen. Konsumen dapat meminta pertanggung jawaban jika pelaku usaha iklan menghasilkan iklan yang tidak sesuai dengan kontrak kerja sama yang telah dilakukan.

b) Bertanggung jawab secara mandiri terhadap konsumen karena konsumen sudah mengalami kerugian atas produk atau jasa yang ditawarkan seperti tidak sesuai dengan contoh komposisi atau mutu pada perjanjian sebelumnya.

c) Memiliki kewajiban untuk memberikan garansi atau jaminan berdasarkan perjanjian yang telah disepakati. Contoh, garansi mengenai penggunaan barang yang dijual dalam waktu I tahun pada konsumen. 
d) Konsumen tidak bisa menuntut pada pelaku usaha jika tidak ada perjanjian mengenai kewajiban pelaku usaha untuk bertanggung jawab pada produk atau jasa yang dijual. Berdasarkan ketentuan Undang-Undang Perlindungan konsumen, konsumen tidak dapat menggunakan alasan Perbuatan Melanggar Hukum.

e) Pelaku usaha tidak memenuhi ganti rugi karena barang yang cacat di kemudian hari dan sesuai dengan perjanjian yang hanya mampu bertanggung jawab sampai pada masa kadaluarsa berakhir, yaitu 4 tahun.

\section{SIMPULAN DAN SARAN}

\section{Simpulan}

Dari penjelasan diatas peneliti dapat menyimpulkan bahwa strict liability atau prinsip pertanggungjawaban mutlak dalam hokum perlindungan konsumen. Produsen berkewajiban mengganti kerugian jasa atau barang yang telah dibeli oleh konsumen sehingga harus bertanggung jawab atas kesalahan yang diperbuat oleh pelaku bisnis sebagaimana yang sudah diatur pada Pasal 19 Undang-Undang No. 8 Tahun 1999 mengenai Perlindungan Konsumen. Ketentuan pertanggungjawaban rnutlak (strict liability) pelaku usaha terhadap konsumen pada aturan proteksi konsumen sudah diatur dalam ketentuan Perlindungan Konsumen UU No. 8 Tahun 1999. Sedangkan pada Pasal 19- 27 UU No. 8 Tahun 1999 terkait pelaku bisnis bertanggung jawab memberikan ganti rugi yang mencakup segala kerugian konsumen,jaminan atau garansi berlaku pada batas waktu sekurang-kurangnya I (satu) tahun, hukuman-hukuman diberikan sesuai dengan UU yang berlaku oleh penegak hukum, dan pembuktian atas kerugian yang dialami oleh konsumen.

\section{Saran}

a. Bagi pemerintah menjadi pihak yang berwenang supaya lebih berperan penting pada pengawasan perlindungan konsumen guna membuat keseimbangan hak dan kewajiban antara pelaku bisnis dengan konsumen sebagai akibatnya bisa menaruh pertanggungjawaban yang baik bagi pelaku bisnis maupun konsumen supaya terciptanya hubungan antara penjual dan pembeli yang tertib dan kondusif.

b. Bagi pelaku bisnis diperlukan supaya pelaku bisnis membuat lebih memperhatikan hukum dan ketentuan perlindungan pada konsumen guna mencegah terjadinya resiko kerugian yang dapat dialami oleh konsumen dan apabila melakukan hubungan yang baik antara pelaku bisnis dengan konsumen maka bisa terjadinya kemajuan usaha yang diperdagangkan oleh pelaku bisnis, sedangkan bagi konsumen supaya lebih berhati-hati dalam menentukan barang dan konsumen diperlukan untuk mengerti hak-haknya berdasarkan Undang-Undang yang berlaku buat kedepannya lebih kondusif dalam pembelian barang-barang tadi sehingga meminimalisir terjadinya kesalahan pada suatu transaksi jual beli.

\section{DAFTAR PUSTAKA}

Ahmad, M. (2013). Prinsip-Prinsip Perlindungan Hukum bagi Konsumen di Indonesia (Cet. 2). Rajawali Pres.Jakarta.

Ahmad, M \& Yodo, S. (2017). Hukum Perlindungan Konsumen (Ed. Revisi). Rajawali Pers.Jakarta.

Awawi Arief Barda. (2007). Masalah Penegakan Hukum dan Kebijakan Hukum Pidana Dalam Penanggulangan Kejahatan. Kencana .Jakarta.

Husni Syawali, \& Neni, S. Imaniyati. (2000). Hukum Perlindungan Konsumen. Mandar Maju.Bandung.

Johnson, P. M. (2003). Kamus Ekonomi-Polirik. Teraju.

NHT Siahaan. (2005). Hukum Konsumen Perlindungan Konsumen Dan TanggungJawab Produk. Panta Rei.Jakarta.

Rahardjo, S. (1977). Pemanfaatan Ilmu-ilmu Sosial bagi Pengembangan llmu Hukum.Alumni. Bandung. 
Jurnal Konstruksi Hukum

Vol. 2, No. 2, 2021

Saefullah, E. (2000). Hukum Perlindungan Konsumen dalam tulisan tanggung jawab produsen dalam era perdagangan bebas. Mandar Maju.Bandung.

Tri, S. K. C. (2014). Hukum Perlindungan Konsumen. Sinar Grafika.Jakarta. 